\title{
The relationship between motives of entrepreneurial behavior and venture maturity
}

\author{
Article history: \\ Received: 20 July 2016 \\ Sent for revision: 6 September 2016 \\ Received in revised form: 29 November 2016 \\ Accepted: 29 November 2016 \\ Available online: 5 April 2017
}

\begin{abstract}
Countries at a different level of development exhibit a variety of entrepreneurial initiatives and activities in terms of motives of entrepreneurial behavior, but also the scope and structure of entrepreneurial ventures. The aim of this paper is to explore the relationship between the degree of economic development and the motives of entrepreneurial behavior. In order to perform a more detailed overview of the research subject, the research area expands on the scope and structure of entrepreneurial activity, with the aim of identifying the impact of the motives of entrepreneurial behavior on the entrepreneurial process observed in its phases. Characteristics of selected variables and the size of the research sample conditioned the usage of the Spearman's correlation coefficient and the Chi-square test. The results indicate a positive correlation between the level of economic development and opportunity motive of entrepreneurial ventures. This motive is also found to be a generator of maturity of entrepreneurial ventures. More specifically, the higher percentage of participation of the entrepreneurial ventures with opportunity motive is associated with a higher percentage of enterprise in more mature stages, which is especially reflected in the group of highly developed countries.
\end{abstract}

Keywords: Entrepreneurship, motives, entrepreneurial process, venture maturity, GEM

\footnotetext{
${ }^{1}$ University of Novi Sad - The Faculty of Economics in Subotica, Serbia

${ }^{2}$ University of Novi Sad - The Faculty of Economics in Subotica, Serbia, bojan.lekovic@ef.uns.ac.rs

3 University of Novi Sad - The Faculty of Economics in Subotica, Serbia 
Bobera D. et al.: The relationship between motives of entrepreneurial behavior and...

\section{Povezanost motiva preduzetničkog ponašanja i zrelosti poduhvata}

Apstrakt: Zemlje različitog stepena razvoja iskazuju različite preduzetničke inicijative $i$ aktivnosti u smislu motiva preduzetničkog ponašanja ali $i$ obima $i$ strukture preduzetničkih poduhvata. Cilj rada predstavlja utvrdjivanje odnosa izmedju stepena ekonomskog razvoja i motiva preduzetničkog ponašanja. Sa namerom što potpunijeg sagledavanja predmeta istraživanja područje analize proširuje se na obim i strukturu preduzetničkih aktivnosti sa ciljem sagledavanja uticaja motiva preduzetničkog ponašanja na preduzetnički proces posmatran prema njegovim fazama. Karkakteristika odabranih varijabli $i$ veličina istraživačkog uzorka uslovile su upotrebu Spirmanovog koeficijenta korelacije i Chi-square test. Rezultati ukazuju na visok stepen pozitivne korelacije izmedju nivoa ekonomskog razvoja i opportunity motive preduzetničkog poduhvata. Navedeni motivi ujedno predstavljaju generator zrelosti preduzetničkog poduhvata. Tačnije, veće procentualno učešće opportunity motive preduzetničkih poduhvata dovodi do većeg procenta poduhvata u zrelijim fazama, što je naročito izraženo u okviru grupe visoko razvijenih zemalja.

Ključne reči: Preduzetništvo, motivi, preduzetnički proces, zrelost preduzetničkog poduhvata, GEM

\section{Introduction}

Countries with different degrees of development exhibit a variety of entrepreneurial initiatives and activities in terms of motives of entrepreneurial behavior but also the scope and structure of entrepreneurial ventures. The impact of the level of economic development is reflected in the national economic and entrepreneurial conditions as direct upgrades. Especially those ambient entrepreneurial conditions are the basic generator for the support of entrepreneurial ventures. The level of development and availability of these elements significantly reflects on the motives of entrepreneurial behavior as well as the scope and structure of the entrepreneurial process. The motives as the determinants of individual behavior are the primary generator of individuals' driving activities. In the literature of the entrepreneurship, there are recognized two main motives for starting entrepreneurial ventures, those are necessity and opportunity. Certainly, these motives of entrepreneurial behavior are one of the reasons for reaching the mature stage of the whole entrepreneurial process. The nature of the necessity and opportunity entrepreneurs and the differences in their socio-demographic characteristics 
Bobera $D$. et al.: The relationship between motives of entrepreneurial behavior and...

and entrepreneurs' aspirations direct attention to the exploration of their impact on the process of successfully passing through a period of incubation of enterprises and achieving the mature phase of the entrepreneurship venture.

Based on the above mentioned, the aim of this paper is to explore the relationship between the degree of economic development and the motives of entrepreneurial behavior, and relation of the motives of entrepreneurial behavior and entrepreneurial process. The subjects of the research are the main motives and stages of entrepreneurship venture. The main purpose of this research lies in the importance of entrepreneurship, which is seen as a generator of the national economy. Namely, since our domestic economic policies and strategies emphasize the importance of entrepreneurship in contemporary economic development, it is important to explore entrepreneurs' aspirations and main motives when starting their business, but also the relation between their motives and the success and survival of their business in the future. In order to explore proposed subject of the research, the authors of this paper stated research hypotheses related to the determining the relation between the level of economic development and motives of entrepreneurial behavior, and the relation between the motives of entrepreneurial behavior and development of entrepreneurial ventures. The methodology of the research included theoretical exploration of the available literature on research subject and the analysis of the available data on entrepreneurial ventures. The main source of the data comes from the GEM project from 2009. Global Entrepreneurship Monitor - GEM represents the world's leading research consortium dedicated to the understanding of the relationship and impact of entrepreneurship on economic development. At the same time, it represents an annual assessment of entrepreneurial activity at the national level. GEM research project in 2009 was conducted in 54 countries worldwide, with a total of 180,000 respondents. The authors used data from 2009 GEM database because that was the last year when the Republic of Serbia participated in the GEM project.

The research was presented in three parts. In the first part authors presented main theoretical views on the motives of entrepreneurship behavior and the process of entrepreneurship venture. In the second part of the paper, there have been presented methodology and data used for the exploration of the proposed research hypotheses. In the third part, authors presented the results of the analysis and certain conclusions derived. 
Bobera D. et al.: The relationship between motives of entrepreneurial behavior and...

\section{Literature review}

\subsection{Motives of entrepreneurs" behavior}

Taking into account the motivation for starting entrepreneurial ventures, we distinguish between two basic types of entrepreneurs': necessity and opportunity, i.e., entrepreneurs which are coerced and those who are guided by the chances. The support to this concept is given by are numerous researchers in the field of entrepreneurship (Gurtoo \& Williams, 2009; Hessels et al., 2008).

In the literature in the field of entrepreneurship, there has been a consensus when it comes to the shaping and theoretical determination of these concepts. Thus, opportunity entrepreneurs are considered as people who run entrepreneurial venture for reasons of profitable exploitation of perceived chances, while the necessity entrepreneurs are identified as people who run venture for reasons of lack of alternatives. In the line with the previous observation Miniti et al. (2005) provides additional support when defining these two groups of entrepreneurs. According to him, entrepreneurs who recognize business opportunity and consequently run enterprise are considered as opportunity entrepreneurs. In contrast, there are entrepreneurs who start a project for reasons of unemployment or dissatisfaction with current job and those are understood as necessity entrepreneurs.

It is noticeable that necessity entrepreneurs have less human and financial capital (Caliendo \& Kritikos, 2009) which leads to the development of business enterprise of lower quality, with less investment and human capital, which influences the lower level of earnings and profits (Preisendorfer \& Vos, 1990). These facts are confirmed in the survey conducted by Block \& Wagner (2010) where the authors confirmed the hypothesis that opportunity entrepreneurs predict more profitable opportunities in contrast to necessity entrepreneurs, leading to higher wages. Also, the research conducted by Block \& Wagner (2007) proves that perceived business chances are more profitably exploited by opportunity entrepreneurs instead of necessity entrepreneurs, while Block \& Sandner (2009) found that necessity entrepreneurs gain lower income (earnings).

Acs (2006) tried to determine the effects of the opportunity and necessity entrepreneurship on economic development. By determining the ratio between opportunity and necessity entrepreneurial ventures and their impact on the revenues of the country, it has been found a positive correlation between the observed variables. In fact, more opportunity entrepreneurial motive caused higher realized income of countries. Since they are highly educated individuals with adequate knowledge and entrepreneurial skills, the 
Bobera $D$. et al.: The relationship between motives of entrepreneurial behavior and...

launching of innovative entrepreneurial ventures is seen as a freedom of choice and not as a necessity. Consequently, a factor of success of these ventures lies in the fact of their entrepreneurial skills and abilities. Since one of the bases of economic growth is recognized in knowledge (Cvjetković, 2015), it can be emphasized the role of opportunity entrepreneurial ventures in generating economic growth. It is assumed that the level of necessity entrepreneurial ventures decreases with the increasing of the level of economic development and stability of the economic environment. This consideration is supported by the attitude of the author Bosma \& Levie (2010) who emphasize low share of the necessity entrepreneurial ventures in highly developed countries. Necessity entrepreneurship, characteristic for less developed countries, is recognized from a number of authors who have conducted research using data from the GEM research, as a factor that is negatively correlated with economic growth and development (Acs \& Varga, 2005; Wenekers et al., 2005; Wong et al., 2005).

\subsection{The process of the development of entrepreneurial venture}

The validity of the methodology of the entrepreneurial process developed by the Global Entrepreneurship Monitor can be located in several facts. The duration of research studies by GEM, and the number of countries involved in this research project indicate the scientific and methodological foundation in terms of detailed exploration of an entrepreneurial activity at all stages of the entrepreneurial process. Available literature in the form of scientific research papers and accessible international comparisons of indicators of entrepreneurial activity during all phases of the entrepreneurial process influenced the identification of the factors of cultural, social and economic environment that directly cause the entrepreneurial aspirations, activities, and attitudes. Ultimately, a comprehensive methodological approach of shaping the entrepreneurial process has resulted in precisely determined phases of the entrepreneurial process, which are scientifically based and factually justified. All the above-mentioned features of the methodology of the entrepreneurial process created by GEM allow comparison of phases and activities within the entrepreneurial process between the countries, which was recognized by the authors of this paper.

The thing that separates successful from unsuccessful entrepreneurs is their ability to detect profitable opportunities. Ardichvili et al. (2003) believe that the identification of opportunities for the creation of a new business enterprise is one of the most important characteristics of a successful entrepreneur. Some other authors also observed the identification of opportunities as a crucial first step and a key phase of the entrepreneurial process (Ozgen \& Baron, 2007). Shane \& Venkataraman (2000) also highlighted the importance of identification of business chances, considering that it is a necessary but not 
Bobera D. et al.: The relationship between motives of entrepreneurial behavior and...

sufficient condition for starting entrepreneurial ventures. Shane (2003) considers an entrepreneurial opportunity as a situation in which one person can create a new framework for re-combining resources in a way that he expects that is will bring him profit. The process of detecting opportunities and development of innovation represents a driving force for an entrepreneur. This is what motivates his personality. Consideration of entrepreneurial activity from the standpoint of whether they are carried by the discovery or creation of opportunities was addressed by numerous authors (Zahra et al, 2008; Venkataraman et al, 2012). The criticism of the consideration of ways to observe or create chances in exhibited Lewin (2015). From his point of view, it is not a scientific research process that requires confirmation, but the emphasis was primarily on the process of spotting opportunities. It is a process based on the evaluation, action, and understanding. Does the observed potential represent a chance for possible profit by entrepreneurs depends on the quality of the business idea. There are a lot of ideas but they all do not represent simultaneously entrepreneurial chances. The successful launching of entrepreneurial ventures preceded a process of successful development of opportunities that include their identification and evaluation (Ardichvili et al., 2003).

According to the definition of the GEM methodology, a nascent entrepreneur is a persons who are trying to start a new entrepreneurial venture, where he expect to be one of the owners or owner of the business, who were active in the last 12 months when it comes to activities aimed to launch entrepreneurial ventures, whose entrepreneurial venture has not yet achieved a positive inflow of funds to cover operating expenses and salaries of employees in the period of three months (Reynolds et al, 2004; Acs et al, 2005). According to Luckgen et al. (2004), nascent entrepreneurs are persons who are, individually or in cooperation with other parties, involved in the process of creating a new business enterprise with the expectation that they will be the owner or one of the owners of the enterprise. The explanation of nascent entrepreneurs also gave Peake \& Marshall (2006), considering them as persons that are in the stage of gestation of the entrepreneurial process and that are active in raising resources and knowledge in order to start the business enterprise. The process of creating entrepreneurial ventures, better known under the term nascent entrepreneurship, is complex and challenging endeavor (Davidson \& Gordon, 2009). This process requires undertaking a wide range of activities such as the development of market-friendly products or services, the provision of financial resources, finding office space, the acquisition of materials and inventions, marketing, sales (Samuelsson \& Davidsson, 2009). Successful implementation of the business concept and its transition to the next phase represents major milestones in the business of an entrepreneur, who guided with the aspirations of growth, innovation, and 
Bobera D. et al.: The relationship between motives of entrepreneurial behavior and...

internationalization of the business comes to a more mature phase of the entrepreneurial process observed by its phases.

\section{Research methodology}

The key problem, as well as the entire orientation of this research, is related to the analysis of the impact of the degree of economic development on the motives of entrepreneurial behavior. In order to provide a more comprehensive exploration of the research problem, the analysis expands on the scope and structure of entrepreneurial activity with the aim of identifying the impact of the motives of entrepreneurial behavior on the development of entrepreneurial ventures, seen its phases. Accordingly, the research set the following operational tasks:

- Determining the relation between the level of economic development and motives of entrepreneurial behavior;

- Determining the relation between the motives of entrepreneurial behavior and development of entrepreneurial ventures, seen its phases.

Determined problem area, as well as objectives of the research point to the following research assumptions set out in the form of hypotheses. Defined hypotheses are based on previous empirical researches in this field and in the available literature.

H1: There is a positive relationship between highly developed countries and entrepreneurial ventures based on opportunity motives.

H2: Countries grouped by the level of economic development have a different ratio of the motives for entrepreneurial ventures.

H2a: Opportunity motives represent a generator of the maturity of an entrepreneurial venture, especially in innovation-driven countries.

The main source of the data comes from the GEM project from 2009. Global Entrepreneurship Monitor - GEM represents the world's leading research consortium dedicated to the understanding of the relationship and impact of entrepreneurship on economic development. At the same time, it represents an annual assessment of entrepreneurial activity at the national level. GEM research project in 2009 was conducted in 54 countries worldwide, with a total of 180,000 respondents, and represents the most relevant database in terms of academic disciplines such as management, entrepreneurship, innovation management, etc. The authors used data from 2009 GEM database because that was the last year when the Republic of Serbia had participated in the worldwide GEM project. To test the connection between the following continuous variables the authors will use the Spearman's correlation test. Whether the motives of entrepreneurial behavior affect the achievement of 
Bobera D. et al.: The relationship between motives of entrepreneurial behavior and...

more mature phase of the entrepreneurial process will be explored with the usage of the Chi-square method. The authors decided to use this statistical analysis because of the categorical variables in this part of the research.

Table 1. Variables used in the research

\begin{tabular}{ll}
\hline Code & Variable description \\
\hline C1.gdppc & GDP per capita \\
\hline C2.TEA09omvu & $\% 18-64$ Opportunity motive: improvement (TEA) \\
\hline C2.TEA09pd & $\% 18-64$ Opportunity motive: increase income (TEA) \\
\hdashline C2.TEA09nez & $\% 18-64$ Opportunity motive: independence (TEA) \\
\hline C2.TEA09nuz & $\% 18-64$ non-opportunity motive, necessity: maintain income \\
C2.oppornec & Opportunity or necessity motive for start up \\
\hline C3.nasc & Active past year (part) owner, no wages yet \\
\hline C3.babybu & Owns-manages business with income $<3.5$ years \\
\hline C3.estbu & Owns-manages business with income $>3.5$ years \\
\hline
\end{tabular}

Source: GEM research 2009

Also, during the examination of the relations between the above-mentioned variables, the authors took into consideration the achieved level of economic development of surveyed countries. In order to obtain a more detailed analysis, the impact of observed variables was presented in the context of the countries grouped in three categories of the achieved level of economic development: factor driven, efficiency driven and innovation-driven economies. The list of variables used for the purpose of research is presented in table 1.

\section{Results and discussion}

The relationship between opportunity ventures which are driven by improvement in the overall entrepreneurial activity (C2.TEA09omvu) and the level of achieved economic development presented in the nominal amount of GDP per capita was tested by using Spearman's rho correlation test. There has been found a moderate positive correlation between the intensity of these two variables, $r=0.592, n=52, p<0.000$, which points that a higher degree of achieved economic development presented in the nominal amount of GDP per capita means higher percentage of opportunity ventures driven by improvement in the overall entrepreneurial activity (C2.TEA09omvu).

The relationship between opportunity ventures driven by independence within the overall entrepreneurial activity (C2.TEA09nez) and the level of achieved economic development presented in the nominal amount of GDP per capita was also tested by using Spearman's rho correlation test. There has been found a strong positive correlation between the intensity of these two variables, $r=0.745, n=52, p<0.000$, which points that a higher degree of 
Bobera D. et al.: The relationship between motives of entrepreneurial behavior and...

achieved economic development presented in the nominal amount of GDP per capita means higher percentage of opportunity ventures driven by independence within the overall entrepreneurial activity (C2.TEA09nez).

Table 2. Correlation between motives and GDP per capita

\begin{tabular}{|l|l|l|r|r|r|}
\hline \multicolumn{5}{|c|}{ Correlations } \\
\hline \multicolumn{3}{|c|}{} & $\begin{array}{c}\text { C2.TEA09 } \\
\text { omvu }\end{array}$ & \multicolumn{1}{c|}{ C2.TEA09nez } & C2.TEA09nuz \\
\hline \multirow{2}{*}{$\begin{array}{l}\text { Spearman's } \\
\text { rho }\end{array}$} & C1gdppc & $\begin{array}{l}\text { Correlation } \\
\text { Coefficient }\end{array}$ &, $592^{* *}$ &, $745^{* *}$ &,$- 555^{* *}$ \\
\cline { 3 - 6 } & &, 000 &, 000 &, 000 \\
\cline { 3 - 6 } & Sig. (2-tailed) & 52 & 52 & 52 \\
\cline { 2 - 6 } & $\mathrm{N}$ & 2-tailed). & & \\
\hline
\end{tabular}

Source: Authors analysis based on GEM data

Spearman's rho correlation test was used to test the relationship between necessity driven ventures within the overall entrepreneurial activity (C2.TEA09nuz) and the level of achieved economic development presented in the nominal amount of GDP per capita. There has been found a moderate negative correlation between the intensity of these two variables, $r=-0.555$, $\mathrm{n}=52, \mathrm{p}<0.000$, which points that a higher degree of achieved economic development presented in the nominal amount of GDP per capita means a smaller percentage of necessity driven ventures within the overall entrepreneurial activity (C2.TEA09nuz).

Table 3. Pearson Chi Square test for motives of entrepreneurial venture and entrepreneurial process (Factor-driven countries)

\begin{tabular}{|c|c|c|c|c|c|c|c|c|c|}
\hline & \multicolumn{2}{|c|}{ C3.nasc } & & \multicolumn{2}{|c|}{ C3.babybu } & & \multicolumn{2}{|c|}{ C3.estbu } \\
\hline & & \begin{tabular}{l|l} 
NO & \\
\end{tabular} & YES & & NO & YES & & NO & YES \\
\hline \multirow{2}{*}{ 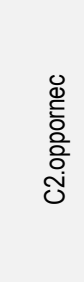 } & 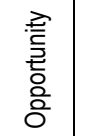 & $69,40 \%$ & $58,40 \%$ & $\begin{array}{l}\text { 总 } \\
\text { 产 } \\
\text { 응 }\end{array}$ & $59,00 \%$ & $68,00 \%$ & $\begin{array}{l}\text { 롤 } \\
\text { 产 } \\
\text { 응 }\end{array}$ & $59,40 \%$ & $73,30 \%$ \\
\hline & 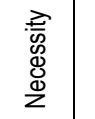 & $30,60 \%$ & $41,60 \%$ & 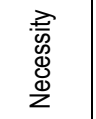 & $41,00 \%$ & $32,00 \%$ & 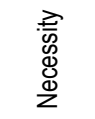 & $40,60 \%$ & $26,70 \%$ \\
\hline \multicolumn{10}{|c|}{ Chi-Square Tests } \\
\hline & Value & $\begin{array}{l}\text { Asymp. } \\
\text { Sig. (2- } \\
\text { sided) }\end{array}$ & Phi & Value & $\begin{array}{l}\text { Asymp. } \\
\text { Sig. (2- } \\
\text { sided) }\end{array}$ & Phi & Value & $\begin{array}{l}\text { Asymp. } \\
\text { Sig. (2- } \\
\text { sided) }\end{array}$ & Phi \\
\hline $\begin{array}{l}\text { Pearso } \\
\text { n Chi- } \\
\text { Square }\end{array}$ & $14,803^{a}$ &, 000 & 0,094 & $9,500^{\mathrm{a}}$ & ,002 & $-0,07$ & $13,446^{a}$ & ,000 & $-0,089$ \\
\hline
\end{tabular}

Source: Authors analysis based on GEM data

Industrija, Vol.45, No.1, 2017 
Bobera $D$. et al.: The relationship between motives of entrepreneurial behavior and...

According to the data in Table 3, we can conclude that there is a statistically significant relation between the entrepreneur's motives and the phase of entrepreneurship venture. If the main motive for entrepreneurship is the business opportunity, higher share of the entrepreneurs will be more successful in three phases (C3.nasc. $=58,4 \%$; C3.babybu. $=68 \%$; C3estbu. $=73.3 \%$ ) in greater extent than if the main motive is the necessity (C3.nasc. $=41.6 \%$; C3.babybu. $=32 \%$; C3estbu. $=26,7 \%$ ). These associations are statistically significant (C3.nasc. Chi square $=14.803, \quad p=0.000$; C3.babybu.Chi square $=9.500, p=0.002$; C3estbu. Chi square $=13.446$, $\mathrm{p}=0.000$ ) and the level of association between these variables was week (Phi=0,07 to 0.09 ).

Table 4. Pearson Chi Square test for motives of entrepreneurial venture and entrepreneurial process (Efficiency-driven countries)

\begin{tabular}{|c|c|c|c|c|c|c|c|c|c|}
\hline & \multicolumn{2}{|c|}{ C3.nasc } & & \multicolumn{2}{|c|}{ C3.babybu } & & \multicolumn{2}{|c|}{ C3.estbu } \\
\hline & & NO & YES & & NO & YES & & NO & YES \\
\hline \multirow{2}{*}{ 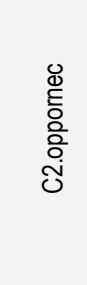 } & $\begin{array}{l}\text { 릉 } \\
\text { 突 } \\
\text { 응 }\end{array}$ & $67,46 \%$ & $61,87 \%$ & $\begin{array}{l}\text { 童 } \\
\text { 음 } \\
\text { 응 }\end{array}$ & $62,10 \%$ & $68,00 \%$ & $\begin{array}{l}\text { 졸 } \\
\text { 흥 } \\
\text { 응 }\end{array}$ & $63,20 \%$ & $64,30 \%$ \\
\hline & 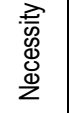 & $32,54 \%$ & $38,13 \%$ & 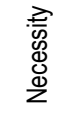 & $37,90 \%$ & $32,00 \%$ & 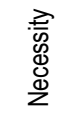 & $36,80 \%$ & $35,70 \%$ \\
\hline \multicolumn{10}{|c|}{ Chi-Square Tests } \\
\hline & Value & \begin{tabular}{l|l} 
Asymp. \\
Sig. (2- \\
sided)
\end{tabular} & Phi & Value & $\begin{array}{l}\text { Asymp. } \\
\text { Sig. (2- } \\
\text { sided) }\end{array}$ & Phi & Value & $\begin{array}{l}\text { Asymp. } \\
\text { Sig. (2- } \\
\text { sided) }\end{array}$ & Phi \\
\hline $\begin{array}{l}\text { Pearso } \\
\text { n Chi- } \\
\text { Square }\end{array}$ & 6,70 & ,010 & 0,051 & 6,582 & ,010 & $-0,05$ & ,110 & ,741 & $-0,07$ \\
\hline
\end{tabular}

Source: Authors analysis based on GEM data

The data in Table 4 show that there is a statistically significant relation between the entrepreneur's motives and the phase of entrepreneurship venture. If the main motive for entrepreneurship is the business opportunity, a higher share of the entrepreneurs will be more successful in three phases (C3.nasc. $=61.87 \%$; C3.babybu. $=68 \%$; C3estbu. $=64.30 \%$ ) to a greater extent than if the main motive is the necessity (C3.nasc. $=38.13 \%$; C3.babybu. $=32 \%$; C3estbu. $=35.7 \%$ ). These associations are statistically significant (C3.nasc.Chi square $=6.70, p=0.010$; C3.babybu. . Chi square $=6.582, p=0.010$ ) and the level of association between these variables was week ( $\mathrm{Phi}=0,05$ to 0.07 ). 
Bobera D. et al.: The relationship between motives of entrepreneurial behavior and...

Table 5. Pearson Chi Square test for motives of entrepreneurial venture and entrepreneurial process (Innovation-driven countries)

\begin{tabular}{|c|c|c|c|c|c|c|c|c|c|}
\hline & \multicolumn{2}{|c|}{ C3.nasc } & & \multicolumn{2}{|c|}{ C3.babybu } & & \multicolumn{2}{|c|}{ C3.estbu } \\
\hline & & \begin{tabular}{|l|l} 
NO & \\
\end{tabular} & YES & & NO & YES & & NO & YES \\
\hline \multirow{2}{*}{ 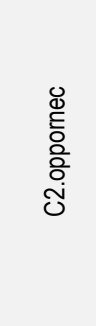 } & 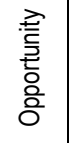 & $81,50 \%$ & $78,10 \%$ & 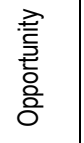 & $77,50 \%$ & $84,30 \%$ & 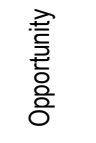 & $78,10 \%$ & $84,80 \%$ \\
\hline & 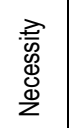 & $18,50 \%$ & $21,90 \%$ & 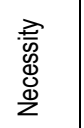 & $22,50 \%$ & $15,70 \%$ & 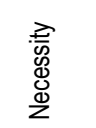 & $21,90 \%$ & $15,20 \%$ \\
\hline \multicolumn{4}{|c|}{ Chi-Square Tests } & & & & & & \\
\hline & Value & \begin{tabular}{l|l} 
Asymp. \\
Sig. (2- \\
sided)
\end{tabular} & Phi & Value & $\begin{array}{l}\text { Asymp. } \\
\text { Sig. (2- } \\
\text { sided) }\end{array}$ & Phi & Value & $\begin{array}{l}\text { Asymp. } \\
\text { Sig. (2- } \\
\text { sided) }\end{array}$ & Phi \\
\hline $\begin{array}{l}\text { Pearso } \\
\text { n Chi- } \\
\text { Square }\end{array}$ & $2,284^{a}$ & ,131 & 0,035 & $8,861^{a}$ & ,003 & $-0,069$ & $5,552^{a}$ & ,018 & $-0,055$ \\
\hline
\end{tabular}

Source: Authors analysis based on GEM data

The data in Table 5 show that there is a statistically significant relation between the entrepreneur's motives and the phase of entrepreneurship venture. If the main motive for entrepreneurship is the business opportunity, a higher share of the entrepreneurs will be more successful in three phases (C3.nasc. $=78.10 \%$; C3.babybu. $=84.30 \%$; C3estbu. $=84.80 \%$ ) to a greater extent than if the main motive is the necessity (C3.nasc. $=21.90 \%$; C3.babybu. $=15.70 \%$; C3estbu. $=15.20 \%$ ). These associations are statistically significant (C3.babybu.Chi square $=5.552 ; \quad p=0.018 ; \quad$ C3.babybu. Chi square $=8.861, p=0.003)$ and the level of association between these variables was week (Phi=0,05 to 0.07).

Figure 2. Influence of entrepreneurial motives on entrepreneurial process

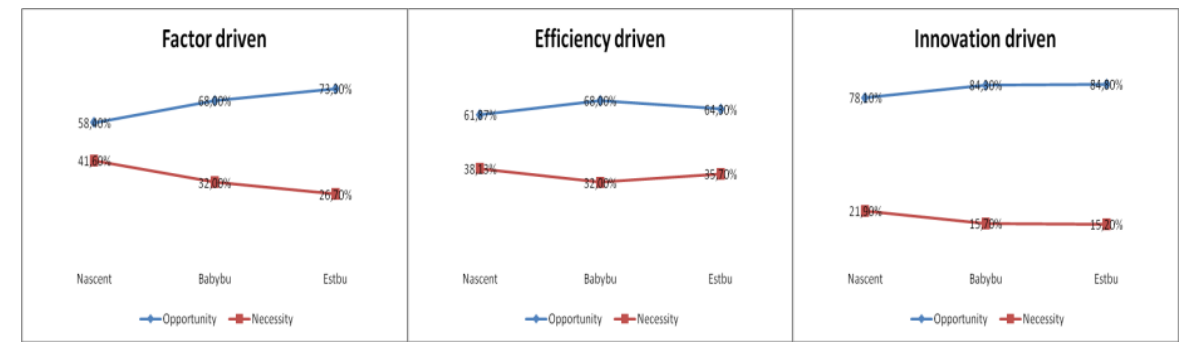

Source: Authors analysis based on GEM data

Industrija, Vol.45, No.1, 2017 
Bobera D. et al.: The relationship between motives of entrepreneurial behavior and...

The results obtained through statistical analyses confirm the research hypothesis $\mathrm{H} 1$. The results of the Spearman's correlation coefficient indicated a positive impact of the degree of economic development expressed as the GDP per capita of the motives of entrepreneurial behavior. Chances from the entrepreneurial environment in many ways represent a direct consequence of developed entrepreneurial conditions which are characteristic of countries that achieved the highest level of development. As such, they are created in order to support entrepreneurial ventures. However, if the basic business conditions are not developed, direct entrepreneurial conditions would have lost their meaning, which leads to the conclusion that the direct entrepreneurial conditions are the upgrade of the basic business conditions designed to develop entrepreneurial initiatives characteristic for highly developed countries. Thus, in the countries with the lower level of development in which the basic elements of the business environment, as a result, have a process of self-employment of individuals, there is a lack of elements of direct entrepreneurial conditions for the generating entrepreneurial ventures based on perceived opportunities. It is, therefore, evident that the higher level of economic development reduces the rate of self-employment of individuals as a form of entrepreneurial activity. On the other hand, there is a significant increase of the participation of opportunity enterprises based on the improvement or on the independence of the individual, as the most prestigious opportunity motives. Entrepreneurs driven by necessity motives when searching for a job make a decision on self-employment. As their primary motive is solving their own employment status, it is unlikely to initiate enterprise with the aim of growth of enterprises and employment of additional workforce, which stems from the nature of the enterprise.

The results obtained through statistical analysis confirm the research hypothesis $\mathrm{H} 2$. The nature of the necessity entrepreneurial ventures, as well as their entrepreneurial characteristics, allow a clear distinction in relation to the opportunity ventures, during all phases of the entrepreneurial process, which is the most visible and the most striking in the established stage of business operations (duration of business more than 42 months). The reason that leads to significant separation of these two groups of entrepreneurs is the high complexity in terms of the maintenance of entrepreneurial ventures and its development. Within the group of opportunity entrepreneurs, there are real entrepreneurs who started a business with the intention and observed chance and with desire for successful and profitable exploitation of the chances. In highly developed countries besides provided high social security, employment opportunities and achieving high earnings, individuals who start entrepreneurial ventures actually have to have a certain motive in the form of exploitation of the observed chances. Also, positive impulses from developed 
Bobera D. et al.: The relationship between motives of entrepreneurial behavior and...

business environment support for the opportunity entrepreneurs in the realization of identified opportunities and a support for the necessity entrepreneurs for strengthening of individual entrepreneurial capacities. Within the countries with the medium level of development, it is indicative the presence of a higher percentage of opportunity entrepreneurial ventures in all stages of the entrepreneurial process. However, the results indicate statistically significant differences in all stages, except in the last one, the most mature stage of the entrepreneurial process. Although there is a significant difference of percentages, this is more a reflection of randomness and lack of precise demarcation of the observed variables. In the medium level of economic development, there is a tendency of declining of necessity and increasing of opportunity entrepreneurial ventures. The lack of statistically significant differences in the final stages of the entrepreneurial process and the lack of an accurate distinction and demarcation of the observed enterprises is caused by the achieved stage of economic development which is seen as a transitory stage. In this transitory phase directed to achieving the highest level of economic development, the elements of the business environment still have not been developed sufficiently to provide support in strengthening the entrepreneurial capacity and their transfer to the opportunity ventures, suitable for reaching a more mature stage of the entrepreneurial process. Within the countries with the lower level of development, it is indicative a higher percentage of opportunity entrepreneurial ventures in all phases of the entrepreneurial process. As seen from the obtained results of statistical analysis, it is a particularly dominant share of opportunity ventures along with reaching more mature phase of the entrepreneurial process. Absolute figures point to a smaller number of opportunity ventures comparing with countries with higher level of development, while in countries with the lower level of development there is the dominant presence of necessity entrepreneurial ventures. However, on the basis of their individual and entrepreneurial characteristics, skills and knowledge, opportunity ventures are experiencing more mature phases. Although this type of entrepreneurs is faced with the underdeveloped business environment, required adequate managerial knowledge and entrepreneurial skills are becoming the most important during its overcoming underdeveloped environment and thereby ensuring that their ventures can reach more mature stage of the entrepreneurial process.

\section{Conclusions}

The results of the conducted statistical analysis confirmed the relations between the degree of economic development of the motives of 
Bobera D. et al.: The relationship between motives of entrepreneurial behavior and...

entrepreneurial behavior, i.e., a higher degree of economic development measured in the form of GDP per capita is positively correlated with the determination of the opportunity motives of entrepreneurial behavior. This observation is also confirmed by Rosa et al. (2006), who state that entrepreneurial ventures in poor countries are guided by motives of survival while in developed countries they are guided by identified opportunities. This statement share Reynolds (2001) and Acs (2005), noting that the increase of poverty influence an increase in the number of necessity entrepreneurial ventures. The motive of survival has been recognized by Fresse and De Kruif (2000) which stated that necessity entrepreneurial ventures, especially in the countries of the African continent, were run because of unemployment and provision of funds to the extent that is sufficient to meet basic needs. Poorer countries have a greater scope of initiated entrepreneurial ventures, and thus the necessary entrepreneurial ventures, as these individuals are guided primarily by increasing income security and the improvement of their own living standards (Benzing and Chu, 2009). The influence of the degree of economic development on the motives of entrepreneurial behavior is evident and indisputable, and according to some authors like Acs (2006), the level of economic development can be expressed through ratios of necessity/ opportunity ventures.

Opportunity ventures have greater potential for growth compared with necessity entrepreneurial ventures. Reynolds et al. (2002) in their study stated that opportunity ventures, unlike necessity, achieve higher growth and employ more people during the first five years of operation, which implies reaching the mature stage of the entrepreneurial process, based on the entrepreneurial aspirations relating to the growth of the enterprise. Drawing on these results Zali et al. (2013) proved the impact of entrepreneurial motives on the growth of entrepreneurial ventures. Olomi (2009) confirmed that necessity entrepreneurs have lower ambitions when it comes to an orientation towards the growth of entrepreneurial ventures. The reason for their lower ambitions for enterprise growth is reflected in their intention of providing selfemployment and wages, while their ambitions of hiring additional workers have lower priority. Calliendo and Kritikos (2010) found that the decrease in the number of necessary entrepreneurial ventures along with mature stages of the entrepreneurial process can be supported by the fact of their inadequate preparation for the launch of the enterprise. Even if necessity entrepreneurial ventures experience more mature phases of the process, it is expected to provide lower levels of capital investment, minimum income, and failure to create new jobs in relation to opportunity entrepreneurs (Santarelli and Vivarelli, 2007; Shane, 2009; Andersson and Wadensjo, 2007). 
Bobera $D$. et al.: The relationship between motives of entrepreneurial behavior and...

During the presentation of the research results, it is necessary to point attention on certain limitation in the study. The data used in this study are the results of collecting samples in 2009 year. However, the necessary resources and available methodology for the implementation of the GEM project, in terms of conceptuality, comprehensiveness, and international comparisons (global dimension) of the results have significant time distance in usability, i.e., the relevance of the research results does not lose its importance in time, like some national research methodologies of any observed phenomenon. The research is based on the observation and analysis of current data, which can also be a potential limitation. Research based on longitudinal data, which are also observations, would allow the consideration of phenomena over time. Also, collected data relating to the category of necessity and opportunity entrepreneurs can be a source of limitation since of the lack of sufficiently clear distinction between these two groups of entrepreneurs in the methodology.

In conducting this research the authors identified additional potential opportunities for future research directions that would have resulted in the development of additional models for the improvement of entrepreneurial activity in the territory of the national economy. An entrepreneurial process as a subject of future research offers additional options when it comes to the understanding of achieved stages of entrepreneurial ventures. The maturity of an entrepreneurial venture in the form of achieved phase of the entrepreneurial process can be displayed via drop-out rates of entrepreneurial ventures in individual stages. The collected data would provide valuable information on the number of abandoned entrepreneurial ventures regarding the phase of the entrepreneurial process and the reasons for the end of the business. In this way, it would be given access to concrete and specific problems of entrepreneurs specific to a particular phase of the entrepreneurial process.

\section{References}

Acs, Z. (2006). How is Entrepreneurship Good for Economic Growth?. Innovations, 1(1), 97-107.

Acs, Z.J., \& Varga, A. (2005). Entrepreneurship, Agglomeration and Technological Change. Small Business Economics, 24(3), 323-334. doi:10.1007/s11187-0051998-4

Acs, Z.J., Arenius, P., Hay, M., \& \& Minniti, M. (2005). The Global Entrepreneurship Monitor, 2004 Executive Report. London Business School / Babson College. 
Bobera D. et al.: The relationship between motives of entrepreneurial behavior and...

Andersson, P., \& Wadensjo, E. (2007). Do the unemployed become successful entrepreneurs?, A comparison between the unemployed, inactive and wage earners. International Journal of Manpower, 28, 604-626.

Ardichvili, A., Cardozo, R., \& Sourav, R. (2003). A theory of entrepreneurial opportunity identification and development. Journal of Business Venturing, 18, 105-123. doi:10.1016/S0883-9026(01)00068-4

Benzing, C., \& Chu, H.M. (2009). A comparison of the motivations of small business owners in Africa. Journal of Small Business and Enterprise Development, 16, 6077.

Block, J.H., \& Wagner, M. (2007). Opportunity recognition and exploitation by necessity and opportunity entrepreneurs: Empirical evidence from earnings equations. In: G.T. Solomon (Ed.), Proceedings of the Sixty-Sixth Annual Meeting of the Academy of Management. 1543-8643.

Block, J., \& Wagner, M. (2010). Necessity and opportunity entrepreneurs in Germany: Characteristics and earnings differentials. Schmalenbach Business Review, 154174.

Block, J., \& Sandner, P. (2009). Necessity and opportunity entrepreneurs and their duration in self-employment: Evidence from German micro data. Journal of Industry, Competition and Trade, 9(2), 117-137.

Bosma, N., \& Levie, J. (2010). Global Entrepreneurship Monitor: 2009 Global Executive Report. Editor.

Caliendo, M., \& Kritikos, A. (2009). 'I want to, but I also need to': Start-ups resulting from opportunity and necessity. IZA DP, 4661,

Cvjetković, M. (2015). Knowledge and quality as the factors of the business operations and competitiveness promotion: Research results from Serbia. Industrija, 43(2), 53-72.

Davidsson, P., \& Gordon, S.R. (2009). Nascent entrepreneur(ship) research: A review. Queensland University of Technology. Eprints. Retrieved from http://eprints.qut.edu.au/19622

Gurtoo, A., \& Williams, C.C. (2009). Entrepreneurship and the informal sector: Some lessons from India. Entrepreneurship and Innovation, 10(1), 1-8.

Hessels, J., Gelderen, M., \& Thurik, R. (2008). Entrepreneurial aspirations motivations, and their drivers. Small Business Economics, 31, 323-339.

Lewin, P. (2015). Entrepreneurial opportunity as the potential to create value. The Review of Austrian Economics, 28, 1-15.

Luckgen, I., Oberschachsiek, D., Sternberg, R., \& Wagner, J. (2004). Nascent Entrepreneurs in German Regions: Evidence from the Regional Entrepreneurship Monitor (REM). IZA Discussion Paper, 1394,

Miniti, M., Arenius, P., \& Langowitz, N. (2005). Global Entrepreneurship Monitor: 2004 Report on woman and Entrepreneurship. Babson Park: Babson College / London Business School.

Olomi, R. (2009). African entrepreneurship and small business development. Dar es Salaam: Otme Company Ltd..

Ozgen, E., \& Baron, R.A. (2007). Social sources of information in opportunity recognition: Effects of mentors, industry networks, and professional $\begin{array}{llll}\text { forums. Journal of } \quad \text { Business } & \text { 174-192. }\end{array}$ doi:10.1016/j.jbusvent.2005.12.001 
Bobera D. et al.: The relationship between motives of entrepreneurial behavior and...

Peake, O., \& Marshall, M.I. (2006). What do We Really Know about Entrepreneurs?, An Analysis of Nascent Entrepreneurs in Indiana. Working Paper, 06-14, Department of Agricultural Economics, Purdue University.

Reynolds, P.D., Camp, S.M., Bygrave, W.D., Autio, E., \& Hay, M. (2001). The Global Entrepreneurship Monitor, 2001 Executive Report. Babson College / London Business School.

Reynolds, P.D., Bygrave, W.D., \& Autio, E. (2004). Global Entrepreneurship Monitor 2003 Executive Report. Babson College / London Business School / Kauffman Foundation.

Rosa, P., Kodithuwakku, S., \& Balunywa, W. (2006). "Entrepreneurial motivation in developing countries: What does "Necessity" and "Opportunity"E entrepreneurship really mean. Frontiers of Entrepreneurship Research, 26(20), 1-14. Article 1

Santarelli, E., \& Vivarelli, M. (2007). Entrepreneurship and the process of firms' entry, survival and growth. Industrial and Corporate Change, 16(3), 455-488. doi:10.1093/icc/dtm010

Samuelsson, M., \& Davidsson, P. (2009). Does venture opportunity variation matter?, Investigating systematic differences between innovative and imitative new ventures. Small Business Economics, 33, 229-255.

Shane, S. (2003). A general theory of entrepreneurship: The individual-opportunity nexus. Cheltenham: Edward Elgar Publishing.

Shane, S., \& Venkataraman, S. (2000). The Promise of Entrepreneurship as a Field of Research. Academy of Management Review, 25(1), 217-226.

Venkataraman, S., Sarasvathy, D.S., Dew, N., \& Foster, W.R. (2012). Reflections on the 2010 AMR decade award: Whither the promise?, Moving forward with entrepreneurship as a science of the artificial. Academy of Management Review, 37(1), 21-33. doi:10.5465/amr.2011.0079

Wong, P.K., Ho, Y.P., \& Autio, E. (2005). Entrepreneurship, Innovation and Economic Growth: Evidence from GEM data. Small Business Economics, 24(3), 335-350. doi:10.1007/s11187-005-2000-1

Zahra, S.A. (2008). The virtuous cycle of discovery and creation of entrepreneurial opportunities. Strategic Entrepreneurship Journal, 2, 243-257.

Zali, M., Faghih, N., Ghotbi, S., Rajaie, S., (2013), "The effect of necessity and opportunity driven entrepreneurship on business growth", International Research Journal of Applied and Basic Sciences, pp. 100-108. 
